\title{
Mengenal Karateristik Pengaturan Tanah Bengkok Di Indonesia
}

\author{
Agung Basuki Prasetyo \\ Fakultas Hukum, Universitas Diponegoro. \\ agung_basuki@live.undip.ac.id
}

\begin{abstract}
Research Aims to find out the characteristics of crooked land regulation in Indonesia. The research method is legal research. the results of the study indicate that the Characteristics of Crooked Land Regulations in Indonesia can be explained through three bases, among them are about crooked land according to customary law, bent land according to Law number 5 of 1960 and crooked land according to Crooked Land according to Indonesian Law No. 6 of 2014. Crooked land has various forms, can be in the form of rice fields, dry land or in the form of fish ponds or ponds. The surrender of land is crooked to the village head and his device, but this will again be the village's right if the Village Head and his apparatus no longer hold office, so that the crooked land will be handed back to the Village Head and Village Equipment who replaced him.
\end{abstract}

Keywords: Crooked Land, Land, Customary Law.

\begin{abstract}
Abstrak
Penelitian Bertujuan untuk mengetahui mengenal karateristik pengaturan tanah bengkok di Indonesia. Metode penelitian merupakan penelitian hukum. hasil penelitian menujukan bahwa Karateristik Pengaturan Tanah Bengkok Di Indonesia dapat dijelaskan melalui tiga dasar, diantaranya adalah tentang tanah bengkok menurut hukum adat, tanah bengkok menurut UU nomor 5 tahun 1960 dan Tanah bengkok menurut Tanah Bengkok Menurut Undang-Undang No. 6 Tahun 2014. Tanah bengkok memiliki bentuk yang bermacam-macam, dapat berupa tanah persawahan, tanah tegalan maupun berupa kolam ikan atau tambak. Penyerahan tanah bengkok kepada kepala desa dan perangkatnya, namun hal tersebut akan kembali menjadi hak desa jika Kepala Desa dan perangkatnya tidak menjabat lagi, sehingga tanah bengkok akan diserahkan kembali kepada Kepala Desa dan Perangkat Desa yang menggantikannya.
\end{abstract}

Kata Kunci: Tanah Bengkok, Pertanahan, Hukum Adat. 


\section{PENDAHULUAN}

Tanah merupakan unsur terpenting dalam keberlangsungan kehidupan makhluk hidup terutama manusia itu sendiri. Proses mempertahankan kehidupan sampai dengan kematian. Tak diragukan lagi tanah merupakan sumber kehidupan manusia, masyarakat dan bangsa itu sendiri. Sehingga tanah menjadi unsur yang tidak akan bisa jauh dari manusia. Tingkat kecenderungan ketergantungan manusia terhadap tanah tidak akan ada habisnya selama tanah itu masih ada.

Tanah yang merupakan permukaan bumi harus diatur dan dikelola secara nasional untuk menjaga kelestarian sistem kehidupan berbangsa dan bernegara, dan amanat konstitusi adalah politik pertanahan dan kebijakan pertanahan diarahkan untuk mewujudkan tanah sebagai sumber untuk sebesar-besarnya bagi kemakmuran rakyat, yang meliputi penguasaan, pemilikan, pemanfaatan dan penggunaan tanah.

Tugas Negara tidak terbatas pada memelihara tata tertib serta melindungi jiwa dan harta kekayaan rakyatnya (Police State), melainkan juga Negara bertugas mewakili kepentingan bersama menjadi lebih luas dan mengusahakan peningkatan kemakmuran yang adil dan merata (Welfare State). Sehingga di dalam melaksanakan tugasnya Negara mempunyai kewajiban memerhatikan kepentingan berama, sehingga hak-hak individu atas tanah dinyatakan mempunyai fungsi nasional.

Negara Republik Indonesia merupakan Negara agraris, yang kebanyakan masyarakatnya bermata pencaharian sebagai petani. Tanah dijadikan sebagai media bercocok tanam dalam pertanian. Indosesia yang dilewati garis khatulistiwa dikaruniai tanah yang sangat subur untuk ditanami berbagai macam hasil bumi, mulai dari hasil pertanian, perkebunan dan lain-lain.

Indonesia adalah Negara yang memiliki peningkatan pembangunan infrastruktur yang sangat pesat. Pesatnya pembangunan di Negara kita, disamping membawa positif yaitu meningkatnya kesejahteraan masyarakat juga membawa dampak negatif yaitu timbulnya berbagai kejahatan. Demikian pula di bidang pertanahan.

Dinamika pembangunan mengakibatkan kebutuhan akan tanah semakin meningkat sedang pada pihak lain persediaan akan tanah sangat terbatas. Sehingga penambahan untuk kebutuhan yang satu akan mengurangi persediaan tanah untuk kebutuhan yang satu akan mengurangi persediaan tanah untuk kebutuhan yang lain. Hal ini disamping menimbulkan alih fungsi tanah dari pertanian ke non pertanian, juga mengakibatkan makin meningkatnya harga tanah. 
Pembangunan infrastruktur untuk kepentingan umum dilakukan dari mulai tingkat nasional, provinsi, kabupaten/kota sampai dengan ditingkat desa. John Salindeko memberikan pengertian kepentingan umum adalah Termasuk kepentingan bangsa dan Negara serta kepentingan bersama dari rakyat, dengan memperhatikan segi social, politik, psikologis, dan Hamkamnas atas dasar asas-asas Pembangunan Nasional dengan mengindahkan Ketahanan Nasional serta Wawasan Nusantara. Desa sendiri merupakan suatu daerah kesatuan masyrakat hukum yang memiliki batas-batas wilayah dan berwenang untuk mengurus dan mengatur kepentigan urusan pemerintahannya sendiri yang diakui dan dihormati hak-hak tradisionalnya selama tidak bertentangan dengan Negara Indonesia.

Suatu desa biasanya dipimpin oleh Kepala Desa dan terkadang dipimpin oleh Kepala Suku tergantung desa tersebut berada. Di Pulau Jawa sendiri biasanya dalam suatu desa dipimpin oleh Kepala Desa. Kepala Desa memiliki wewenang dalam mengatur dan mengurus masyarakat desanya sendiri. Kepala Desa dibantu oleh beberapa perangkat desa dalam melaksankan tugasnya. Kepala Desa beserta jajarannya diberikan bayaran berupa uang dan terkadang mendapatkan tanah bengkok untuk diambil hasil dari pengelolaan tanah tersebut.

Kepala Desa pada dasarnya bertanggung jawab terhadap rakyat desa yang dalam tata cara dan prosedurnya pertanggung jawabannya kepada Bupati atau Walikota melalui Camat. Kepala Badan Permusyawaratan Desa, Kepala Desa wajib memberikan keterangan laporan pertanggung jawabannya, namun harus tetap memberi peluang pada masyarakat melalui BPD untuk mananyakan dan atau memberikan keterangan lebih lanjut terhadap hal-hal bertalian dengan pertaggung jawaban yang dimaksud. Pengaturan lebih lanjut mengenai desa seperti pemebentukan, penghapusan, penggabungan, perangkat pemerintahan desa, keuangan desa dan lain-lain sebagainya dilakukan oleh Kabupaten dan Kota yang ditetapkan dalam Peraturan Daerah (Perda) mengacu pada pedoman yang ditetapkan Pemerintah. 
Undang-Undang No.6 Tahun 2014 mengatur seluk-beluk aturan pemerintahan desa, yang salah satunya adalah pengelolaan aset desa atau tanah bengkok yang selama ini sebagian besar dikelola untuk gaji perangkat desa yang bukan pegawai negeri dan sebagian lainnya dianggarkan untuk pendapatan daerah atau desa tersebut. Pada Bab VII Undang-Undang No.6 Tahun 2014 tentang desa yaitu membahas tentang keuangan desa dan asset desa. Pengaturan tanah bengkok itu sendiri diatur dalam bagian kedua yakni asset desa pada Bab VII, dalam Pasal 76 dan Pasal 77 Undang-Undang No. 6 Tahun 2014 Tentang Desa.

Pengelolaan aset desa yang berupa tanah desa atau tanah bengkok tidak boleh dilakukan dengan semena-mena atas kewenangan pribadi dari seorang Kepala Desa semata namun telah diatur dalam peraturan perundang-undangan yang sah. Pengelolaan kekayaan milik desa dilaksanakan berdasarkan asas kepentingan umum, fungsional, kepastian hukum, keterbukaan, efensiensi, ekfektivitas, akuntabilitas, dan kepastian nilai ekonomi. Pengelolaan milik desa dibahas oleh kepala desa bersama Badan Permusyawaratan Desa berdasarkan tata cara pengelolaan kekayaan milik Desa yang diatur dalam Pasal 77ayat (3) Undang-Undang No. 6 Tahun 2014 Tentang Desa. Berdasarkan uraian termasebut maka tulisan ini akan menguraikan tentang bagaimanakah Karateristik Pengaturan Tanah Bengkok Di Indonesia.

\section{PEMBAHASAN}

Pada bagian pembahasan tentang Mengenal Karateristik Pengaturan Tanah Bengkok Di Indonesia akan menjelasakan tentang tanah bengkok menurut hukum adat, tanah bengkok menurut UU nomor 5 tahun 1960 dan Tanah bengkok menurut Tanah Bengkok Menurut Undang-Undang No. 6 Tahun 2014.

\section{Tanah Bengkok Menurut Hukum Adat}

Sejarah pertumbuhan masyarakat pertama mereka berdiam disuatu pusat tempat atau wilayah yang berbatasan sehingga mereka ini merupakan masyarakat wilayah teritorial, masing-masing kelompok masyarakat tersebut mempunyai hak tertentu atas tanah yang ada disekitarnya, yang disebut beschikkingsrecht. ${ }^{1}$ Sehingga di dalam mengolah hak ulayat atas tanah, maka tanah tersebut digunakan sebagai tempat tinggal atau keperluan lainnya oleh masyarakat secara umum di lingkungan

\footnotetext{
${ }^{1}$ Ter Har Bzn, Asas-Asas dan Susunan Hukum Adat, (Jakarta:Pradnya Pramita, 1983), hlm.72.
} 
hukum adat itu, misalnya untuk perkuburan, atau dipungut hasilnya oleh dan untuk masyarakat serta digunakan dan dinikmati bersama-sama.

Keadaan ini kemudian berkembang, pada individu dalam masyarakat diperbolehkan membuka tanah dengan persyaratan tertentu, akhirnya masyarakat memperbolehkan kepada adat atau kepala desa serta perangkat desa lainnya untuk menggunakan tanah tersebut sebagai tanah bengkok yang dapat dipungut hasilnya selama mereka menjabat, atau diserahi tugas oleh masyarakat desa tersebut, hal ini dimaksud sebagai imbalan dari masyarakat kepada kepala desa dengan perangkatnya atas jerih payahnya memimpin masyarakat. ${ }^{2}$

Tanah bengkok memiliki bentuk yang bermacam-macam, dapat berupa tanah persawahan, tanah tegalan maupun berupa kolam ikan atau tambak. Penyerahan tanah bengkok kepada kepala desa dan perangkatnya, namun hal tersebut akan kembali menjadi hak desa jika Kepala Desa dan perangkatnya tidak menjabat lagi, sehingga tanah bengkok akan diserahkan kembali kepada Kepala Desa dan Perangkat Desa yang menggantikannya.

\section{Tanah Bengkok Menurut Undang-Undang No. 5 Tahun 1960}

Undang-Undang No. 5 Tahun 1960 tentang Peraturan Dasar Pokok-Pokok Agraria (UUPA) yang disahkan pada tanggal 24 September 1960, maka telah menjadi unifikasi terhadap dua hukum yang sebelumnya berlaku di Indonesia, yaitu hukum barat dan hukum adat, yang masing-masing memiliki pengaturan sendirisendiri mengenai tanah. Lahirnya UUPA mengahiri Kebhinekaan (Pluralisme) hukum yang berstruktur tunggal, dalam mencapai terwujudnya kesatuan dibidang hukum tanah, bukan hanya hukumnya yang diunifikasikan, tetapi juga hak-hak atas tanah dan hak-hak jaminan atas tanah yang ada, yang semuanya bersumber pada berbagai perangkat hukum yang lama. Diakhirinya pluralisme dan diciptaknnya hukum tanah yang tunggal oleh UUPA merupakan perubahan yang mendasar. ${ }^{3}$

Hak tanah adat yang sebelumnya diatur dalam Hukum Adat dilakukan ketentuan-ketentuan konversi dalam Undang-Undang No. 5 Tahun 1960 tentang UUPA. Konversi adalah perubahan status tanah. ${ }^{4}$ Menurut ketentuan-ketentuan konversi hak tanah adat dikonversi dalam ketentuan Pasal VI menjadi hak pakai

\footnotetext{
${ }^{2}$ Ibid, hlm. 31.

3 Boedi Harsono, Menuju Penyempurnaan Hukum Tanah Nasional, (Jakarta : Penerbit Universitas Trisakti, 2002) hlm. 11.

${ }^{4}$ C. S. T. Kansil dan Critine S. T. Kansil, Kamus Istilah Aneka Hukum,(Jakarta:Pustaka Sinar Harapan, 2001), hlm. 67.
} 
yaitu: Hak-hak atas tanah yang memberi wewenang sebagaimana atau mirip dengan hak yang dimaksud dalam Pasal 41 ayat (1) seperti disebut dengan nama sebagai di bawah, yang ada pada mulai berlakunya Undang-Undang ini, yaitu : hak vruchtgebruik, gebruik, grant controller, bruikleen, ganggam bauntuik, anggaduh, bengkok, lungguh, pituwas, dan hak-hak lain dengan nama apapun juga yang akan ditegaskan lebih lanjut oleh Menteri Agraria, sejak mulai berlakunya UndangUndang ini menjadi hak pakai tersebut dalam Pasal 41 ayat (1), yang memberi wewenang dan kewajiban sebagaimana yang dipunyai oleh pemegang haknya pada mulai berlakunya Undang-Undang ini, sepanjang tidak bertentangan dengan jiwa dan ketentuan-ketentuan Undang-Undang ini. ${ }^{5}$

Tanah bengkok yang sekarang masih ada di Indonesia secara yuridis telah menjadi Hak Pakai. Hak Pakai tersebut diatur dalam Pasal 41 Undang-Undang No. 5 Tahun 1960, yaitu :

a. Hak Pakai adalah hak untuk menggunakan dan/atau memungut hasil dari tanah yang dikuasai langsung oleh Negara atau tanah milik orang lain, yang memberi wewenang dan kewajiban yang ditentukan dalam keputusan pemberiannya atau dalam perjanjian dengan pemilik tanahnya, yang bukan perjanjian sewamenyewa atau perjanjian pengelolaan tanah, segala sesuatu asal tidak bertentangan dengan jiwa dan ketentuan-ketentuan Undang-Undang ini.

b. Hak pakai dapat diberikan :

a. Selama jangka waktu yang tertentu atau selama tanahnya dipergunakan untuk keperluan yang tertentu.

b. Dengan cuma-cuma, dengan pembayaran atau pemberian jasa berupa apapun.

c. Pemberian hak pakai tidak boleh disertai syarat-syarat yang mengandung unsur-unsur pemerasan. ${ }^{6}$

\section{Tanah Bengkok Menurut Undang-Undang No. 6 Tahun 2014}

Undang-Undang No.6 Tahun 2014 mengatur seluk-beluk aturan pemerintahan desa, yang salah satunya adalah pengelolaan aset desa atau tanah bengkok yang selama ini sebagian besar dikelola untuk gaji perangkat desa yang bukan pegawai

\footnotetext{
${ }^{5}$ Boedi Harsono, op.cit, hlm. 25.

${ }^{6}$ Ibid, hlm. 17-18.
} 
negeri dan sebagian lainnya dianggarkan untuk pendapatan daerah atau desa tersebut. Pada Bab VII Undang-Undang No.6 Tahun 2014 tentang desa yaitu membahas tentang keuangan desa dan asset desa. Pengaturan tanah bengkok itu sendiri diatur dalam bagian kedua yakni asset desa pada Bab VII, dalam Pasal 76 dan Pasal 77 Undang-Undang No. 6 Tahun 2014 Tentang Desa.

Pengelolaan aset desa yang berupa tanah desa atau tanah bengkok tidak boleh dilakukan dengan semena-mena atas kewenangan pribadi dari seorang Kepala Desa semata namun telah diatur dalam peraturan perundang-undangan yang sah. Pengelolaan kekayaan milik desa dilaksanakan berdasarkan asas kepentingan umum, fungsional, kepastian hukum, keterbukaan, efensiensi, ekfektivitas, akuntabilitas, dan kepastian nilai ekonomi. Pengelolaan milik desa dibahas oleh kepala desa bersama Badan Permusyawaratan Desa berdasarkan tata cara pengelolaan kekayaan milik Desa yang diatur dalam Pasal 77 ayat (3) Undang-Undang No. 6 Tahun 2014 Tentang Desa.

Lebih lanjut untuk mengatur status tanah bengkok, diatur dalam Peraturan Pemerintah No. 47 Tahun 2015 sebagai perubahan atas Peraturan Pemerintah No. 43 Tahun 2014 tentang Peraturan Pelaksanaan Undang-Undang No.6 Tahun 2014 tentang desa, dalam PP tersebut dilakukan perubahan pada Pasal 100 tentang belanja desa yaitu dengan adanya tambahan aturan baru tentang status tanah bengkok. Aturan baru tersebut menyebutkan bahwa pendapatan yang bersumber dari hasil pengelolaan tanah bengkok tidak termasuk dalam belanja desa, yang ditetapkan dalam anggaran pendapatan belanja desa dan hasil pengelolahan tanah bengkok tersebut dapat digunakan untuk tambahan tunjangan kepala desa dan perangkat desa selain penghasilan tetap dari tunjangan dari APB Desa.

\section{SIMPULAN}

Hasil penelitian Menunjukan bahwa Karateristik Pengaturan Tanah Bengkok Di Indonesia dapat dijelaskan melalui tiga dasar, diantaranya adalah tentang tanah bengkok menurut hukum adat, tanah bengkok menurut UU nomor 5 tahun 1960 dan Tanah bengkok menurut Tanah Bengkok Menurut Undang-Undang No. 6 Tahun 2014. Tanah bengkok memiliki bentuk yang bermacam-macam, dapat berupa tanah persawahan, tanah tegalan maupun berupa kolam ikan atau tambak. Penyerahan tanah bengkok kepada kepala desa dan perangkatnya, namun hal tersebut akan kembali menjadi hak desa jika Kepala Desa dan perangkatnya tidak menjabat lagi, 
sehingga tanah bengkok akan diserahkan kembali kepada Kepala Desa dan Perangkat Desa yang menggantikannya.

\section{Daftar Pustaka}

Ahmad dan Rizaldi. 2017. Jalan Berliku Menuju Bandara Baru, angkasapura magazine.

Amiruddin, Zainal Asikin. 2004. Pengantar Metode Penelitian Hukum. Jakarta : Raja Grafindo Persada.

Bzn, Ter Har. 1983. Asas-Asas dan Susunan Hukum Adat. Jakarta : Pradya Pramita.

Gunanegara. 2008. Rakyat dan Negara Dalam Pengadaan Tanah Untuk Pembangunan Umum. Jakarta : Tata Nusa.

Harsono, Boedi. 1995. Hukum Agraria Indonesia, Sejarah Pembentukan Undang-Undang Pokok Agraria, Isi dan Pelaksanaannya. Jakarta : Djembatan.

Kansil, C.S.T. 2001. Kamus Istilah Aneka Hukum. Jakarta : Sinar Harapan..

KBBI, Tim. 2001. Kamus Besar Bahasa Indonesia. Jakarta : Balai Pustaka.

Koeswahyono, Imam. 2008. Melacak Dasar Konstitusional Pengadaan Tanah Untuk Kepentingan Pembangunan Bagi Umum. Artikel

Parlindungan, A.P. 1993. Komentar Atas Undang-Undang Pokok Agraria. Bandung : Mandar Maju.

Perangin, Effendi. 1994. Hukum Agraria Di Indonesia, Suatu Telaah Dari Sudut Pandang Praktisi Hukum. Jakarta : Raja Grafindo Persada.

Salindeho, John. 1987. Masalah Tanah Dalam Pembangunan. Jakarta : Sinar Grafika.

Salle, H.A, dkk. 2010. Hukum Agraria. Makasar : AS Publishing.

Santoso, Urip. 2006. Hukum Agraria \& Hak-Hak Atas Tanah. Jakarta : Prenada.

Soekanto, Soerjono. 1986. Pengantar Penelitian Hukum. Jakarta : UI Press.

Suandra, I Wayan. 1991. Hukum Pertanahan Indonesia. Jakarta : Rieka Cipta.

Supriadi. 2009. Hukum Agraria. Jakarta : Sinar Grafika.

Syamsudin, M. 2007. Oprasionalisasi Penelitian Hukum. Jakarta : Raja Grafindo Persada.

Widjaja, H.A.W. 2007. Penyelengaraan Otonomi di Indonesia. Jakarta : Rajawali Pers. 